\title{
Forgiveness and Reconciliation in Transitional Justice Practices
}

\author{
Neelke Doorn \\ Centre for Ethics, Radboud Universiteit Nijmegen, the Netherlands
}

\begin{abstract}
In the last decades the notions of forgiveness and reconciliation are applied more and more in the public sphere. In the present paper it is claimed that forgiveness in transitional justice practices is often difficult if not impossible to achieve, and that it could generate counterproductive processes. It is unclear what 'collective forgiveness' is, if it is a realistic concept at all. The expectation of forgiveness seems to generate much resistance, even when former oppressors take up responsibility or do show regret. Often past-sensibilities are too strong, and in many victim-groups self-respect is lacking. Moreover, the role of emotions in public (and mediated) settings remains obscure. These complexities raise the question whether forgiveness is an appropriate ideal to aim at in transitional justice practices, especially when participants are involved in attempts at reconciliation in more or less coercive ways. To give up the ideal of forgiveness does however not imply that reconciliation is unattainable. Alternative accounts of reconciliation are presented which do not start from forgiveness. These alternative accounts show that reconciliation is possible, but it seems important for former victims to regain some sense of self-worth and recognition by others first. Only then people can enter into the long process of rebuilding relationships of trust with former wrongdoers.
\end{abstract}

\section{Introduction}

Until recently, the notions of forgiveness and reconciliation were typically applied in the realm of private life. However, in the last decades these notions are applied more and more in the public sphere. Restorative justice conferences, truth commissions as a way of accounting for gross human rights violations are just a few of the examples where forgiveness and reconciliation are at stake.

Questions arise about when, what and whom to forgive. Forgiveness manifests compassion for wrongdoers but does this mean that the gift of forgiveness is always a moral act? How does forgiveness relate to our feelings of justice? Is there such a thing as unforgivable evil? Forgiveness is somewhat paradoxical. On the one hand it is a free gift; on the other hand it can be subject to conditions or an attitude of the wrongdoer (e.g., repentance, acknowledgment). Even more problematic is the notion of forgiveness if victims are already dead. Is it possible to ask someone else than the primary victim for forgiveness? But conversely, is it possible to refuse forgiveness on behalf of the dead? What if a group of people is responsible for a certain wrongdoing: can there be such a thing as collective responsibility or collective guilt? These questions are even more urgent when forgiveness is reflected upon in the public sphere. In the private sphere forgiveness is generally viewed of as a prerequisite for reconciliation. However, given the problematic aspects of forgiveness in the context of transitional justice processes this would lead us to conclude that reconciliation is impossible to achieve. This conclusion however is premature. Alternative accounts of reconciliation are presented which do not start from forgiveness. These alternative accounts show that reconciliation is possible, but it seems important for former victims to regain some sense of self-worth and recognition by others first.

The present paper aims at presenting an inventory of scholarly interpretations and views on forgiveness and reconciliation in the context of transitional justice practices. Starting from the notion of forgiveness, the typical aspects of the transitional justice context are discussed. These are successively: the collective involved, the public context and the promotion of forgiveness by others (institutional setting). From this discussion it will follow that forgiveness in the context of transitional justice is a highly problematic notion and that forgiveness is unlikely to occur. In the third section reconciliation is focussed on. After discussing the relation between forgiveness and reconciliation 
different accounts of reconciliation are presented, together with the conditions for reconciliation. In the last section these insights are coupled to forms of reconciliation policy.

\section{Forgiveness in transitional justice practices: three problematic issues}

Forgiveness is usually viewed as the overcoming of feelings of revenge, moral hatred, indignation or some other feelings that are related to anger (Roberts 1995). As such it implies an identity transforming process within the victim. So far most scholars (more or less) agree. However, where some authors defend a unilateral or intrasubjective view of forgiveness, making it an issue of the victim irrespective of attitudes of the wrongdoer (see, e.g., Holmgren 1994, Enright et al 1994), the majority of authors defend an intersubjective view of forgiveness. According to this view forgiveness is conditional to the attitude of the wrongdoer. Acknowledgment, repentance, accountability are just some of the possible conditions. If we translate these conditions to the context of transitional justice practices problems arise, which are discussed in the remainder of this section.

\section{Collective aspects of forgiveness}

The notions of acknowledgment, repentance, accountability are problematic when a wrong is committed by a group of people, which is often the case in the situations that are at stake in the context of transitional justice practices. Who is responsible for the wrong committed? Can groups show repentance? And if collective forgiveness is about the overcoming of feelings, similar to forgiveness in the private sphere, how must we view those feelings: can groups have feelings? Except for the topic of collective guilt and collective responsibility, which is widely addressed (but not solved!) in philosophical and legal literature, the collective aspects of remorse, resentment and other moral feelings have received scarce attention in literature. Only few authors explicitly discuss this collective aspect of the emotions involved.

Govier and Verwoerd (2002a) discuss the practice of institutional apology. Following the work of sociologist Nicholas Tavuchis (1991) and philosopher Jean Harvey (1995) they defend the claim that it is not a categorical mistake to think of an institution or collective as being responsible for wrongdoing, apologizing and seeking to make moral amends. However, offering forgiveness on behalf of a group goes further than speaking the words 'I forgive you'. Where apologizing can be viewed as a form of speech act, forgiveness has the character of a process involving emotions and the commitment not to act from hostilities rooted in the transgression by the wrongdoer (Pettigrove 2006: 486).

Pettigrove discusses two ways that we might meaningfully speak about collective emotions. First, collective emotions might refer to emotions experienced by a significant percentage of the individuals of whom the collective is made up. A second way of speaking about collective emotions refers to the structural features of the collective that reinforce the experience of a certain emotions among its members. These can be either formalized structural features or informal features. The author gives the example of the anti-Japanese sentiment reflected in the Chinese educational curriculum and the government's encouragement of anti-Japanese protests (p. 491). Whereas the former emotion refers to the emotion shared by (a part of) the collective, the second type of emotion refers to the collective itself (the collective's emotion). However, if we conceive of collective emotion as the emotion shared by the majority of its members it remains to be seen in what extent it differs from the emotion at the individual level. It seems that forgiveness is then still something that happens at the individual level, be it in a public context. In that case it is important to see how these 'public aspects' affect the emotional dynamics. If we conceive of collective emotion in the second sense (i.e., as the collective's emotion) I think forgiveness is not the right concept to apply. Van Tongeren (2000a,b) has shown that forgiveness is an intersubjective act in a situation where that same intersubjectivity is harmed. To speak of this intersubjectivity at the collective level seems contradictory. Although we might speak of harms committed on the level of the collective, forgiveness is something that happens between individuals. Hence, if we speak of collective forgiveness it is not as much the collective aspect that is important, but it is the public aspect.

Summarizing, there are conceptual objections to the notion of collective forgiveness. Either forgiveness occurs between individuals that make up the collective - and hence it is not a collective that forgives or is forgiven but it is the individual who forgives or is forgiven - or it is not forgiveness but something else that is at stake. In the former case, it is important to know how the public context affects the individual's emotional dynamics. In the latter case, it does make sense to speak of 'normalized relations between groups in which the policies of one are no longer hostile to members of 
the other' (Pettigrove 1991: 496). But to talk of 'normalized relations' is something different than identity transformation and the overcoming of feelings of hatred and revenge.

\section{Public aspects of forgiveness}

In the previous subsection it was found that to be able to speak of forgiveness in the context of transitional justice practices, we should take a deeper look into the public aspects. To make sense of public forgiveness, we should look into detail to the emotions of the individuals and how these are affected. The literature shows some hiatus on the topic of emotional dynamics involved in public forgiveness and reconciliation attempts. Although mostly viewed similar as forgiveness in the private sphere, i.e. as 'the overcoming of feelings of resentment and anger', public forgiveness is not widely discussed in terms of feelings and emotions. An exceptional case is forgiveness in the context of restorative justice conferences, in which ample attention is paid to the role of moral emotions such as shame, guilt, remorse etc. In the literature on transitional justice, on the contrary, these emotions are almost viewed as given. ${ }^{1}$ To put it bluntly: victims have pain and acknowledgment and the uncovering of the truth will help to overcome that pain. However, following the intersubjective view of forgiveness, it seems to be a perilous undertaking to discuss forgiveness, promoted by a commission, without paying attention to the emotional dynamics involved between the victim and the wrongdoer. The function of feelings such as shame, guilt and remorse in the public forgiveness process needs closer examination. They can multiply in the presence public attention, and eventually interact with economic and political interests (Griswold 2007).

In this regard philosophical analysis might be supplemented with insights from social sciences. The study described in Manzi and Gonzaléz (2007), for example, is a valuable first attempt to gain insight in the role of cognitive and emotional dynamics in post-conflict situations. They empirically studied forgiveness and reparation related to important cognitive (victimization, demand for outgroup remorse, and demand for truth) and emotional (anger, collective guilt, and shame) variables. It was found that forgiveness does not convey the same meaning for groups in conflict and that they are associated with different cognitive and emotional variables. They concluded that people appeared not to be ready to forgive unless their feelings of anger towards the opposing group have diminished. Svašek (2002), in her study of 'transitions' in post-socialist Europe found that emotional dynamics may provide a locus of resistance to change, and consequently, hamper further reconciliation.

In summary, emotions play a crucial role in public forgiveness practices. Scholarly literature, however, focusses on economic, political, legal and social dimensions of these transitions. Further research is needed on how the emotions, eroused by the public context, affect the victims' attitude towards their former wrongdoers and vice versa. Neglecting these emotions may hamper the possibilities of genuine pacification. Contrary to intimate relationships, where people are more prone to be touched by sincere emotions, the public setting will hamper rather than trigger empathic resonance. As such it is questionable whether forgiveness is an appropriate ideal to aim at.

\section{The promotion of forgiveness by others}

The third aspect of forgiveness that I will discuss is the institutional promotion of it, for example by a Truth Commission. Most people agree on the impossibility to forgive on behalf on others. Substitutional forgiveness is impossible. But this holds the other way around as well: no one can refuse to forgive on behalf of others. As such the use of concepts from the forgiveness discourse in case a victim has died seems inappropriate. However, just as there are primary, secondary (relatives of primary victims) and tertiary victims (the society), it is possible to offer primary, secondary and tertiary forgiveness (Verwoerd 2007). E.g., parents of a son who has been shot by a racist killer can offer forgiveness for the wrong done to them, viz. the killing of their son, but they cannot offer forgiveness on behalf of the dead son. Analogously, the state can offer the same wrongdoer forgiveness for the tertiary harm, i.e., violating the law. This solution seems a bit academic. Primary and secondary victims might feel the offering of tertiary forgiveness or the granting of amnesty by the government as a lack of acknowledgment of their own suffering. If a society pays no heed to

\footnotetext{
${ }^{1}$ Svašek (2002), for example, studied the 'transitions' in post-socialist Europe, and she found that the emotional dynamics involved in these transitions has been virtually ignored by scholars in favor of economic, political, legal and social dimensions of these phenomena.
} 
brutalities and offenses suffered by many of its citizens, it further damages these vulnerable people because the disregard can be as devastating as the original wrong itself. In literature on penal law, therapy and treatment, this lack of acknowledgment has been termed secondary victimisation (Govier and Verwoerd 2002a: 71; Symonds 1980). Although noticed by some (amongst whom Boraine 1996; Elster 2000; Gutmann and Thompson 2000; Hayner 2000; Rotberg 2000; Govier and Verwoerd 2002a), not many authors who describe (the dilemmas involved in) reconciliation processes explicitly address the question of how the commission's emphasis on forgiveness affects the victims. It is questionable whether people really feel free not to offer forgiveness if forgiveness is being promoted on such a large scale. The result will most probably be false forgiveness and a resistance to further reconciliation (Cf., Svašek 2002; Huyse 2003).

Griswald (2007) conceives of forgiveness and apology as valuable private and civic virtues that run the risk of corruption when put to social and political use. An officially encouraged culture of forgiveness and apology runs the risk of of politicizing the two. One can think of the 're-education' camps in China and Cambodia where coercion or pressure by a group reduces the gesture of forgiveness to a theatrical gesture on the political stage. Hamber (2003) states that the individual healing is often at odds with political, social and international political demands on people to leave the past behind. If not sufficient social justice is ensured to complement the individual healing process, the national forgiveness attempts process can be experienced as 'false reconciliation' by the victims, especially in the absence of full truth and justice. This feeling of 'false reconciliation' is intensified when victims feel that the social place in which they can vent their anger is closed down.

The limited effect of the institutional promotion of forgiveness by the TRC is confirmed by empirical studies. Some victims who testified to the South African Truth and Reconciliation Commission (TRC) felt that they were forced to reconcile or expected to forgive the perpetrators (Hamber 2007, Hamber, Maepa, Mofokeng and Van der Merwe 1998). Based on an analysis of transcripts of the South African TRC Chapman (2007) found that former victims and members of their families who testified at the violations hearings rarely mentioned the topics forgiveness and reconciliation unless prompted so, and that those who did were generally not inclined to forgive the perpetrators. Concerning the perpetrators, they appeared to be reluctant to acknowledge their wrongdoing or to offer meaningful apologies, expressions of regret, or some form of compensation to those who had suffered. Based on these data, the effect of the TRC in terms of the promotion of forgiveness seems limited. Moreover, although most scholars clearly state that forgiving is not the same as forgetting, victims often equate forgiveness with pardoning or think that it implies forgetting. As such the promotion of forgiveness might be an unintended offence to the victims who feel that they simply need to forget the harm done to them. According to the view of social scientists working in the field of political science, this feeling is not unfounded. The political push toward forgiveness can too easily be exploited by politicians to hide the truth about the past (Hamber 2007).

Summarizing, in this section three problematic aspects of forgiveness in the transitional justice practices are discussed. Apart from the conceptual objection to collective forgiveness, empirical research is needed into the emotional dynamics involved in pacification processes and the institutional setting of forgiveness. In the next section it will be shown that the foregoing does not force us to give up the ideal of reconciliation altogether.

\section{Reconciliation in transitional justice practices}

Reconciliation and forgiveness are often mentioned together. Except for the conceptual distinction between the two - forgiveness refers to the identity transforming process within the victim, reconciliation involves the coming together of two (or more) people - reconciliation is also the more secular notion of the two. Forgiveness, as a moral act, has a strong religious connotation, with different meanings in different religious communities (Haas 2004). Reconciliation, on the other hand, can both be framed from a religious as from a secular perspective. Its central place in transitional justice is just one illustration of how the notion of reconciliation transcends the boundaries between the sacred and the secular and enters the political domain.

In a rather general way, reconciliation prevents, once and for all, the use of the past as the seed of renewed conflict (Huyse 2003). Some authors explicitly define reconciliation as the end of a process, the ultimate goal (see, e.g., Roberts 1995; Yandell 1998; Coleman 1998; Foster 2000; Pollefeyt 2004). 
According to this view forgiveness is the means to reach reconciliation. Roberts (1995), for example, states that "the teleology of forgiveness is reconciliation." (p. 299) Pollefeyt (2004) argues that "forgiveness is possible without reconciliation. Reconciliation, however, is not possible without forgiveness. A relation that is transformed, but in which the evildoer is not forgiven, cannot be called a relation in the fullest sense of the word." (p. 63)

It is questionable whether this reasoning holds for a public context as well. First, in the private sphere, people can choose to engage into a relationship. The kind of relationships that are at stake in the public sphere, have a more 'unavoidable' character: Israeli people cannot ignore the presence of Palestinian people, the black South Africans cannot do as if there are no white South Africans, so they must try to find some way of living together. Second, in order to forgive someone, one may need to talk to the wrongdoer, hear his or her narrative. The identity transformation we speak of if forgiveness is at stake, does at least require a reframing of the wrongdoer by the victim. It is questionable whether this reframing can occur without trying to get into some sort of dialogue, and hence relation, with the wrongdoer.

It seems that reconciliation can occur at different levels. Most authors who hold the view that forgiveness involves more than reconciliation, defend a view in which reconciliation can take place in varying degrees. It is not an all-or-nothing concept (see, e.g., Villa-Vicencio 2000; Knight 2004; Govier \& Verwoerd 2002b; Verwoerd 2007). Reconciliation implies "the restoration and sometimes the establishment of a hitherto non-existent relationship of trust" (Villa-Vicencio 2000: 208) or the "coming together after a rift, a rift that undermines trust between the parties" (Govier \& Verwoerd 2002b: 185). The deeply personal matter of forgiveness is something different. Not forgiveness but some form of trust is the prerequisite for reconciliation.

Knight (2004) rethinks reconciliation and forgiveness in the light of pleading guilty and pardon. By confessing, a wrongdoer faces the other "in deed and in introspection" (p. 33), which enables him to restore a more authentic relationship with the other. It does, however, not entitle the wrongdoer to forgiveness, even if the confession is accompanied with genuine remorse. Sometimes it may not be appropriate to seek forgiveness in the first place but to aim for an enlarged sense of human connection and responsibility. As such a confession can be restorative and healing, a movement towards relational wholeness. If a relation is restored in its wholeness, this may lead to forgiveness. In other cases, it may not lead to forgiveness but to the promise of reconciliation. Not forgiveness but engagement and relational wholeness are the central notions according to this view.

Applied in a public context the layered approach of reconciliation seems to be more promising than the view according to which forgiveness is the sine qua non for reconciliation.

\section{Conditions for reconciliation}

Given this layered approach of reconciliation, how can we frame reconciliation at the macro-level and what are the conditions for reconciliation to take place? Grob (2004) discusses reconciliation in the context of the Israeli-Palestinian conflict and he points to the self-critique that lies at the heart of all genuine reconciliation. Each side of the conflicting parties must "radically call into question the dominant story or narrative that has guided its adoption of positions during the course of conflict" ( $p$. 200), hereby not suggesting that there is only one Palestinian narrative or one Zionist narrative. Susan Dwyer (1999) goes further. Not just the calling into question of existing narratives but the construction of a new master narrative lies at the core of a genuine reconciliation process. She defends a notion of reconciliation in terms of tensions in personal narratives. Reconciliation, according to this view, can be understood as the incorporation of those tensions. In the light of the South African TRC, Dwyer tries to give an account of reconciliation at the national level. The core notion is that of bringing apparently incompatible descriptions of events into narrative equilibrium. This is why uncovering of what happened is so important. The first thing that is required is a clear view of what happened: who did what to whom when. But the task is then to move beyond the mere statements of agreed-upon facts, and move toward mutually acceptable interpretations of those events. The latter does not require that all involved agree on a single interpretation, only that they are mutually tolerant of a limited set of interpretations. Dwyer makes a clear distinction between forgiveness and reconciliation. Arriving at such a narrative equilibrium might, but need not, involve an apology and an offer of forgiveness. As such, neither an apology from the wrongdoer nor forgiveness offered by the victim is prerequisite for 
reconciliation, but "the construction of a coherent narrative that encompasses both atrocities of apartheid and the hope for a peaceful, respectful coexistence of political equals."

Govier and Verwoerd (2002b) criticize Dwyer's account of reconciliation for being too far removed from the realities of relationships between individuals and groups to plausibly be construed as the core of reconciliation. "It is people, not their narratives or theories, who are alienated from each other and may need to be reconciled." (p. 183) They argue that the reconciling of what were incompatible accounts of events is not strictly necessary for individuals or groups. People may agree to come together, even while continuing to differ about contested events. Govier and Verwoerd are right in saying that narrative coherence is not a necessary condition for reconciliation. However, if the different parties are willing to come together without agreeing on what exactly happened, they have to agree on what is acceptable and what is not. ${ }^{2}$ Even if people do not agree on the content of other people's narrative, they should adopt a sort of meta-consensus concerning the legitimacy of other people's narratives, comparable to a Habermas' notion of communicative rationality, which does not require substantive uniformity of rationality but which does require some procedural or formal agreement on what counts as rational (Habermas 1992).

A second point of criticism, raised by Govier and Verwoerd is the fact that there are contexts in which narrative reconciliation is not the main issue that is at stake. People can remain angry and alienated from each other, even while they render some aspects of their narrative coherent. Even if achieving a significant degree of narrative coherence in the wake of serious conflict would be a significant achievement and one that would surely require some communication and cooperation, it is the joint cooperative process that leads to this narrative coherence and the attitudinal shifts emerging from that process, which contributes to reconciliation, not the narrative coherence itself ( $p$ 184).

I think both Govier / Verwoerd and Grob / Dwyer have a point. I agree with Grob and Dwyer that narratives play a crucial role in reconciliation and that recognition of the legitimacy of the other's narrative is a crucial condition for reconciliation to take place. However, Govier and Verwoerd (2007) correctly argue that reconciliation is about human relationships that are restored and not narratives. Hence, the narrative coherence itself cannot offer reconciliation. To proceed from here, it might be a good starting point to look at an important obstacle of reconciliation. Especially for victims, the experience of being wronged, can dramatically affect their feeling of self-worth and, consequently their trust in others, which is conceptually elaborated by Axel Honneth (1992). Honneth developed an account of identity-formation, which requires the recognition by others. The normative self-image of each and every individual is dependent on the possibility of being continually backed up by others. Those who have been wronged by others can develop a negative self-image, which "carries with it the danger of an injury that can bring the identity of the person as a whole to the point of collapse." (1992, 131 - 132). If we follow Honneth's account of identity-formation, one's relationship to oneself is an intersubjective process. It requires the capacity to trust one's own sense of what one needs or wants (self-confidence), a sense of possessing universal dignity, which has to do with viewing oneself as entitled to the same status and treatment as every other person (self-respect) and the absence of systematic denigration from outside one's subculture (self-esteem). This capacity is a precondition for self-realization in any human community. As such both accounts of reconciliation move too fast, and maybe too far, in their quest for reconciliation. The gap between questioning one's own narrative and accepting the other's might be a gap too wide to bridge if one is deprived of the basic feelings of selfworth. The conception of reconciliation proposed by Govier / Verwoerd is also too demanding in its focus on trust between victims and former wrongdoers. For the victims, to be able to reconcile with their former wrongdoers it seems important to regain some sense of self-worth and recognition by others first. Only then people can start to rebuild relationships of trust with their former wrongdoers.

\section{Reconciliation policy}

Given the view that both accounts of reconciliation seem to ask too much too soon, what should be done instead? Without suggesting that a single recipe for pacification can be given, it is worthwhile to consider the framework of reconciliation policy outlined by Huyse (2003). He distinguishes three stages within the reconciliation process and he emphasizes the need for a safe environment in the

\footnotetext{
${ }^{2}$ Cf. Zalaquett's remark that "reconciliation is not possible if the two main parties do not have a secret agreement about what they see as mutually important." (quoted in Antjie Krog, 1998, p. 132).
} 
earliest stage. 'Building confidence and trust' (stage 2) and 'Towards Empathy' (stage 3) are the other two stages. Huyse argues that without a minimum of physical security there is no prospect of any progress along the path to reconciliation. Only after this stage, people can start to build confidence and trust and ultimately gain some form of empathy. Attempts to improve the social conditions might be as important in this stage of the process as attempts to promote dialogue between the victims and wrongdoers (Cf. De Lange 2000; Lyster 2000; Kritz 1995), which is reflected in the four pillars of reconciliation policy: healing, justice, truth-telling and reparation. Together these four pillars lay the foundations for the gradual creation of various outcomes of reconciliation (Huyse 2003: 24). The four pillars are intertwined: without reparation, justice and truth no healing can occur. Accordingly, reconciliation policy should be aimed at a balance between the four instruments. As long as structural injustices in the political, legal or economic domains remain, reconciliation will not be sustainable. Any reconciliation attempt must therefore be aimed at a removal of unjust inequalities, and a commitment by the society in general, and the former wrongdoers in particular, to take responsibility for the past (in particular truth telling) and future (healing and reparation).

\section{Conclusions}

The previous sections showed that the notion of forgiveness in the context of transitional justice practices is a difficult undertaking. First, there is the conceptual objection against the notion of the collective that is at stake when we talk about forgiveness in transitional justice practices. Second, and maybe more important, there are empirical objections. How do the emotions involved affect the pacification process and what kind of forgiveness can be offered if forgiveness is publicly promoted? Without a thorough understanding of the emotional dynamics involved, pacification attempts may be fruitless (in the positive case) or counterproductive in the worst case scenario.

These complexities raise the question whether forgiveness must be viewed as a necessary condition in peacemaking at all. In collective processes it is questionable whether forgiveness is an appropriate ideal to aim at, especially when participants are involved in attempts at reconciliation in more or less coercive ways. For communities that have suffered under severe violence and humiliation, it seems more important to regain some basic sense of self-worth and trust in one's own identity. Reconciliation in its most general form should aim at the prevention to use the past as the seed of renewed conflict. Sustainable reconciliation requires the absence of structural injustices, both in a political, legal and economic sense. Only then people can enter into the long process of rebuilding relationships of trust with former wrongdoers.

\section{References}

Boraine, A., 1996. 'Accountability and Reconciliation: Rebuilding Trust in the Aftermath of Conflict'. In: Workshop on Reconciliation for Bosnia. London: Project on Justice in Times of Transition. Unpublished partial transcripts.

Chapman, A.R., 2007. 'Truth Commissions and Intergroup Forgiveness: The Case of the South African Truth and Reconciliation Commission'. Peace and Conflict: Journal of Peace Psychology 13(1), pp. 51 - 69.

Coleman, P.W., 1998. 'The Process of Forgiveness in Marriage and the Family'. In: Exploring Forgiveness. R.D. Enright and J. North (eds.). Wisconsin/London: The University of Wisconsin Press.

De Lange, J., 2000. 'The historical context, legal origins and philosophical foundation of the South African Truth and Reconciliation Commission'. In: Looking Back Reaching Forward. Reflections on the Truth and Reconciliation Commission of South Africa. Ch. Villa-Vicencio and W. Verwoerd (eds.). Cape Town: Juta Publishing Co./ London: Zed Books.

Dwyer, S., 1999. 'Reconciliation for Realists'. Ethics \& International Affairs 13 (1), 81-98.

Elster, J., 2004. Closing the Books: Transitional Justice in Historical Perspective. Cambridge: Cambridge University Press.

Enright, R.D., and the Human Development Study Group, 1994. 'Piaget on the moral development of forgiveness: Reciprocity or identity', Human Development, 37, pp. 63 - 80.

Foster, D., 2000. 'What makes a perpetrator? An attempt to understand'. In: Looking Back, Reaching Forward. Reflections on the Truth and Reconciliation Commission of South Africa. Ch. Villa-Vicencio and W. Verwoerd (eds.). Cape Town: University of Cape Town Press.

Govier, T. and W. Verwoerd, 2002a. 'The promise and Pitfalls of Apology', Journal of Social Philosophy, Vol. 33 (1), Spring 2002, pp. $67-82$.

Govier, T. and W. Verwoerd, 2002b. 'Trust and the Problem of National Reconciliation', Philosophy of the Social Sciences, Vol. 32 (2), June 2002, pp. $178-205$.

Griswald, C.L., 2007. Forgiveness. A Philosophical Exploration. Cambridge: Cambridge University Press. 
Grob, L., 2004. 'The Israeli-Palestinian Conflict: Just Reconciliation in the Shadows of the Holocaust'. In: After-words. PostHolocaust Struggles with Forgiveness, Reconciliation, Justice'. D. Patterson and J.K. Roth (eds.). Seattle/London: University of Washington Press.

Gutmann, A. and D. Thompson, 2000. 'The Moral Foundations of Truth Commissions'. In: Truth vs Justice. The Morality of Truth Commissions. R.I. Rotberg and D. Thompson (eds.). Princeton, New Yersey: Princeton University Press.

Haas, P.J., 2004. 'Forgiveness, Reconciliation, and Jewish Memory after Auschwitz'. In: After-words. Post-Holocaust Struggles with Forgiveness, Reconciliation, Justice'. D. Patterson and J.K. Roth (eds.). Seattle/London: University of Washington Press.

Habermas, J., 1992. 'Themes in post-metaphysical thinking' (W. Hohengarten, Trans.). In: Post-metaphysical thinking: Philosophical essays (pp. 28-57). Cambridge, MA: MIT Press.

Hamber, B., 2003. 'Healing'. In D. Bloomfield, T. Barnes, and L. Huyse (Eds.), Reconciliation after violent conflict: A handbook (pp. 19-33). Stockholm, Sweden: International Institute for Democracy and Electoral Assistance.

Hamber, B., 2007. 'Forgiveness and Reconciliation: Paradise Lost or Pragmatism'. Peace and Conflict: Journal of Peace Psychology 13(1), pp. $115-125$.

Hamber, B., T. Maepa, T. Mofokeng and H. Van der Merwe, 1998. Survivors' perceptions of the Truth and Reconciliation Commission and suggestions for the final report. Submission to the Truth and Reconciliation Commision. Johannesburg: Centre for the Study of Violence and Reconciliation.

Harvey, J., 1995. 'The Emerging Practice of Institutional Apologies'. International Journal of Applied Philosophy, 1995, 9 (2), pp. $57-65$

Hayner, P. B., 2000. 'Same species, different animial: how South Africa compares to truth commissions worldwide'. In: Looking Back Reaching Forward. Reflections on the Truth and Reconciliation Commission of South Africa. Ch. VillaVicencio and W. Verwoerd (eds.). Cape Town: Juta Publishing Co./ London: Zed Books.

Holmgren, M.R., 1994. 'Forgiveness and the Intrinsic Value of Persons'. American Philosophical Quaterly 30, pp. 331 340.

Honneth, A., 1992. The Struggle for Recognition. Original German title: Kampf um Anerkennung. Cambridge: Polity Press.

Huyse, L., 2003. 'The process of reconciliation'. In D. Bloomfield, T. Barnes, and L. Huyse (Eds.), Reconciliation after violent conflict: A handbook (pp. 19-33). Stockholm, Sweden: International Institute for Democracy and Electoral Assistance.

Knight, H.F., 2004. 'The Face of Forgiveness in a Post-Holocaust World'. In: After-words. Post-Holocaust Struggles with Forgiveness, Reconciliation, Justice'. D. Patterson and J.K. Roth (eds.). Seattle/London: University of Washington Press.

Kritz, N.J., 1995. Transitional Justice. How Emerging Democracies Reckon with Former Regimes. Volume 1. General Considerations. Washington: United States Institute of Peace.

Krog, A., 1998. Country of my skull. Guilt, sorrow, and the limits of forgiveness in the new South Africa. New York: Three Rivers Press.

Lyster, R., 2000. 'Amnesty: the burden of the victims'. In: Looking Back Reaching Forward. Reflections on the Truth and Reconciliation Commission of South Africa. Ch. Villa-Vicencio and W. Verwoerd (eds.). Cape Town: Juta Publishing Co./ London: Zed Books.

Manzi, J. and R. Gonzaléz, 2007. 'Forgiveness and Reparation in Chile: The Role of Cognitive and Emotional Intergroup Antecedents'. Peace and Conflict: Journal of Peace Psychology 13(1), pp. 71 - 91.

Pettigrove, G., 2006. 'Hannah Arendt and Collective Forgiving'. In: Journal of Social Philosophy, 37(4), Winter 2006, pp. 483-500.

Pollefeyt, D., 2004. 'Forgiveness after the Holocaust'. In: After-words. Post-Holocaust Struggles with Forgiveness, Reconciliation, Justice'. D. Patterson and J.K. Roth (eds.). Seattle/London: University of Washington Press.

Roberts, R.C., 1995, 'Forgivingness'. In: American Philosophical Quarterly, 32, pp. 289 - 306.

Rotberg, R.I., 2000. 'Truth Commissions and the Provision of Truth, Justice, and Reconciliation'. In: Truth vs Justice. The Morality of Truth Commissions. R.I. Rotberg and D. Thompson (eds.), 2000. Princeton, New Yersey: Princeton University Press.

Symonds, M., 1980. The "second injury" to victims (special issue). Evaluation and Change, 36-38.

Svašek, M. 2002. 'The politics of emotion: Emotional discourses and displays in post-Cold War contexts'. Focaal - European Journal of Anthropology 39 (1), pp. 9 - 27.

Tavuchis, N., 1991. Mea Culpa: A Sociology of Apology and Reconciliation. Stanford: Stanford University Press.

Van Tongeren, P., 2000a. 'Is vergeving een deugd?'. In: Rechtvaardigheid en Verzoening. Over de fundamenten van de moraal in een tijd van geweld. E. Brugmans, G. Glas and S. Waanders (eds.), Uitgeverij DAMON bv.

Van Tongeren, P., 2000b. 'Schaamte en vergeving. Naar aanleiding van B. Schlink, Der Vorleser'. In: Is vergeving mogelijk? Over de mogelijkheid en moeilijkheid van vergeving, vooral in verband met oorlogsmisdaden. $\mathrm{P}$. van Tongeren (ed.). Best: Uitgeverij DAMON bv.

Verwoerd, W., 2007. Equity, Mercy, Forgiveness. Interpreting Amnesty within the South Africa Truth and Reconciliation Commission . Forthcoming.

Villa-Vicencio, Ch., 2000. 'Getting on with life'. In: Looking Back, Reaching Forward. Reflections on the Truth and Reconciliation Commission of South Africa. Ch. Villa-Vicencio and W. Verwoerd (eds.). Cape Town: University of Cape Town Press.

Yandell, K.E., 1998. 'The Metaphysics and Morality of Forgiveness'. In: Exploring Forgiveness. R.D. Enright and J. North (eds.). Wisconsin/London: The University of Wisconsin Press. 